\title{
Pengaruh Kompetensi Pegawai Dan Iklim Organisasi Terhadap Kualitas Pelayanan Di Unit Pelaksana Pelayanan Terpadu Satu Pintu Kota Administrasi Jakarta Barat
}

\author{
A. H. Rahadian ${ }^{1}$, Albertina Novi ${ }^{2}$; Sri Sundari ${ }^{3}$, Mary Ismowati ${ }^{4}$ \\ Rahadian_ah@yahoo.com, albertinanovi@gmail.com, \\ sri.sundari@stiami.ac.id; mary.ismowati@stiami.ac.id
}

\begin{tabular}{ll}
\hline ARTIKEL INFO & ABSTRACT \\
\hline $\begin{array}{l}\text { Keywords: employee } \\
\text { competence, }\end{array}$ & $\begin{array}{l}\text { This study aims to determine how much Effect of Employee } \\
\text { Competence and Organizational Climate on the Quality of Customer } \\
\text { the Quality of Customer } \\
\text { Service. }\end{array}$ \\
& $\begin{array}{l}\text { Service in One Stop Integrated Service Unit West Jakarta } \\
\text { independent variables and the dependent variable is operationalized } \\
\text { by research method as follows: Sampling is done by using the } \\
\text { technique sampling; Scoring of answers of respondents using a Likert } \\
\text { Scale Technique; using Quantitative Descriptive Data Analysis. From } \\
\text { the above results, it can be concluded that the hypothesis that the } \\
\text { authors propose is acceptable, because there is a positive Effect of } \\
\text { Employee Competence and Organizational Climate either partially or } \\
\text { simultaneously on the Quality of Customer Service in One Stop } \\
\text { Integrated Service Unit West Jakarta Administration. }\end{array}$
\end{tabular}

\section{PENDAHULUAN}

Dari penelitian selama ini, pelayanan yang diberikan pemerintah khususnya di Unit Pelaksana Pelayanan Terpadu Satu Pintu Pada Kantor Walikota Administrasi Jakarta Barat terlihat masih adanya keluhan yang disampaikan masyarakat baik secara langsung maupun tidak langsung. Hal ini terlihat dari masih rendahnya produktifitas kerja dan disiplin dari Aparatur Sipil Negara (ASN) tersebut, serta masih kurangnya sarana kerja yang memadai. Dalam hal penyediaan pelayanan perizinan, petugas birokrasi sering kali memberikan prosedur yang sangat rumit dan cenderung berbelit-belit, jika mekanisme yang rumit terus tetap berjalan, otomatis membuat masyarakat menjadi malas dan enggan dalam mengurus perizinan.Disamping itu, lamanya pelayanan membuat masyarakat sering lama menunggu, dan banyak dari masyarakat yang kurang memahami prosedur pelayanan sehingga sering menanyakan secara berulang-ulang kepada petugas. Maka, pemerintah perlu mencari solusi untuk mengatasi masalah-masalah tersebut.

Konsekuensi lebih lanjut dari tuntutan ini mengharuskan pemerintah menyediakan aparat yang memiliki dedikasi dan disiplin tinggi serta loyalitas pengabdian yang penuh pada tugas yang menjadi tanggung jawabnya dan berorientasi pada pelayanan masyarakatsebagai abdi negara dan abdi masyarakat. Sedangkan pelayanan publik yang dimaksud disini adalah sesuai dengan Undang-Undang Nomor 25 tahun 2009 tentang Pelayanan Publik dijelaskan Pelayanan publik adalah kegiatan atau rangkaian kegiatan dalam rangka pemenuhan kebutuhanpelayanan sesuai dengan peraturan perundang-undangan bagi setiap warga negara dan penduduk atas barang, jasa, dan/atau pelayanan administratif yang disediakan oleh penyelenggara pelayanan publik. Setelah Undang-undang diturunkan ke Peraturan Pemerintah Republik Indonesia Nomor 96 Tahun 2012 tentang Pelaksanaan Undang-Undang Nomor 25 tahun 2009 tentang Pelayanan Publik. Selanjutnya Peraturan Presiden Nomor 97 Tahun 2014 tentang Penyelenggaraan Pelayanan Terpadu Satu Pintu. Selanjutnya Peraturan Daerah Nomor 12 Tahun 2013 tentang Penyelenggaraan Terpadu Satu Pintu yang menjelaskan Penyelenggaraanya Pelayanan yang ada di baik di tingkat provinsi sampai kelurahan dan yang terkahir dijelaskan juga di Peraturan Gubernur Nomor 57 tahun 2014 tentang Pelaksanaan Peraturan Daerah Nomor 12 Tahun 2013 tentang Penyelenggaraan Pelayanan Terpadu Satu Pintu. 
Dalam kaitannya terhadap pelayanan perizinan, pemerintah berusaha menciptakan suatu sistem pelayanan yang optimal. Salah satu dari tindakan pemerintah tersebut adalah dengan dikeluarkannya suatu kebijakan Pelayanan Terpadu Satu Pintu (PTSP). Dengan adanya PTSP, aparatur pemberi pelayanan harus benar-benar ditata, diperbaharui, dan dibenahi untuk mengubah citra aparatur yang sebelumnya dipandang lamban dan tidak transparan menjadi efektif sesuai dengan tujuan pelayanan publik

Dinas Penanaman Modal dan Pelayanan Perizinan Terpadu Satu Pintu (DPMPTSP) merupakan salah satu perangkat pemerintah daerah Pemprov DKI Jakarta, khususnya Unit Pelaksana Pelayanan Terpadu Satu Pintu Pada Kota Administrasi Jakarta Barat yang menerapkan sistem pelayanan satu pintu. Unit Pelaksana Pelayanan Terpadu Satu Pintu sebagai instansi yang khusus bertugas memberikan pelayanan mengenai perizinan yang langsung bersinggungan kepada masyarakat, pada dasarnya dapat dikatakan sebagai terobosan baru atau inovasi manajemen pemerintah daerah.yang diharapkan mampu memberikan pelayanan publik yang berkualitas sesuai dengan tuntutan dan harapan masyarakat.

Perangkat birokrasi di Indonesia juga belum benar-benar menyadari bahwa memberikan pelayanan yang terbaik merupakan cerminan dari semangat pengabdian. Sebagian besar pola pikir aparatur birokrasi masih didominasi pikiran dan perilaku "dilayani", "menghambat", "mempersulit", "memperumit urusan sederhana", dan "tertutup". ( Rahadian, AH, 2004: 60)

Faktor pendukung yang berpengaruh langsung terhadap mutu pelayanan yang diberikan, adalah faktor manusia yang memberikan pelayanan tersebut. Manusia/pegawai (Customer Service Officer) yang melayani masyarakat harus memiliki kemampuan melayani pelanggan secara tepat dan cepat. Disamping itu, Customer Service Officerharus memiliki kemampuan dalam berkomunikasi, sopan santun, ramah, dan bertanggung jawab penuh terhadap yang dilayaninya.Kompetensi merupakan suatu kemampuan untuk melaksanakan atau melakukan suatu pekerjaan atau tugas yang dilandasi atas keterampilan dan pengetahuan serta didukung oleh sikap kerja yang dituntut oleh pekerjaan tersebut.

Pegawai adalah garda terdepan dalam penyelenggaraan kegiatan organisai dalam melakukan pelayanan.Oleh karena itu untuk pencapaian tujuan organisai makaperlu didukung oleh adanya tim kerja yang solid, dengan menciptakan suasana kerja yang nyaman dan kondusif. Suasana kerja yang kondusif merupakan faktor yang tidak dapat diabaikan dalam suatu sistem pengelolaan manajemen organisasi. Pentingnya iklim kerja yang kondusif selayaknya mendapat perhatian yang serius dari pihak manajemen organisasi, karena tugas-tugas akan dapat terselesaikan secara baik apabila tercipta suatu iklim kerja yang mampu menumbuhkan semangat kerja yang tinggi, yang selanjutnya akan mempercepat proses penyelesaian tugas yang menjadi tanggung jawab pegawai.

Berdasarkan paparan yang dikemukakan diatas, terdapat dua factor yang dianggap memiliki pengaruh yang cukup signifikan terhadap Kualitas Pelayanan di Unit Pelaksana Pelayanan Terpadu Satu Pintu Kota Administrasi Jakarta Barat. Pertama adalah Kompetensi pegawai, menurut Albanese dalam Hayes (2000:96) menyatakan bahwa kompetensi merupakan keterampilan dan atau karakteristik dari pribadi seseorang yang mampu mendukung penciptaan keunggulan bersaing suatu organisasi. Yang kedua adalah Iklim organisasi, menurut Davis dan Hewstrom (1995:67), "Iklim organisasi adalah lingkungan dimana para pegawai suatu organisasi melakukan pekerjaan mereka. Iklim mengitari dan mempengaruhi segala hal yang bekerja dalam organisasi sehingga iklim dikatakan sebagai suatu konsep yang dinamis.

Dari penjelasan diatas maka dalam penelitian ini ditentukan judul : Pengaruh Kompetensi Pegawai dan Iklim Organisasi Terhadap Kualitas Pelayanan di Unit Pelaksana Pelayanan Terpadu Satu Pintu Kota Administrasi Jakarta Barat.

Berdasarkan latar belakang masalah yang telah dikemukakan di atas maka dapat dirumuskan permasalahan penelitian sebagai berikut :

1. Seberapa besar pengaruh Kompetensi Pegawai Terhadap Kualitas Pelayanan di Unit Pelaksana Pelayanan Terpadu Satu Pintu Kota Administrasi Jakarta Barat?

2. Seberapa besar pengaruh Iklim Organisasi terhadap Kualitas Pelayanan di Unit Pelaksana Pelayanan Terpadu Satu Pintu Kota Administrasi Jakarta Barat?

3. Seberapa besar pengaruh Kompetensi Pegawai dan Iklim Organisasi secara bersama-sama terhadap Kualitas Pelayanan di Unit Pelaksana Pelayanan Terpadu Satu Pintu Kota Administrasi Jakarta Barat? 


\section{METODE}

Metode dalam penelitian ini menggunakan pendekatan kuantitatif dan untuk memperkaya data dan lebih memahami fenomena sosial yang diteliti, selanjutnya terdapat usaha untuk menambahkan informasi kualitatif pada data kuantitatif.

Dalam penelitian survai terdiri dari dua tahap, yakni tahap teoritisasi yang menggunakan konsep dan proposisi untuk menggambarkan fenomena sosial yang diamati dan diperlukan teori untuk menerangkan mengapa satu konsep berhubungan dengan konsep lainnya. Sehingga teridentifikasi variabel penelitian, yakni aspek tertentu konsep yang dapat diukur, dan merumuskan hipotesa atas dasar teori dan proposisi yang ditentukannya. Kemudian tahap selanjutnya adalah tahap empirisasi mencakup identifikasi variabel penelitian, perumusan hipotesa, penentuan definisi operasional, penyusunan hipotesa statistik, penyusunan instrumen penelitian dan penentuan sampel penelitian (Efendi, 2000: 32).

Populasi yang menjadi obyek penelitian meliputi masyarakat yang menerima pelayanan di Unit Pelaksana Pelayanan Terpadu Satu Pintu Kota Administrasi Jakarta Barat selama 1 bulan yaitu bulan Desember Tahun 2016 sebanyak 1265 masyarakat. Dalam penentuan jumlah sampel, peneliti menggunakan rumus Slovin (Umar, Husein, 2004:107) sebagai berikut.

$$
\mathrm{n}=\frac{\mathrm{N}}{1+\mathrm{Ne}^{2}}
$$

Dari perhitungan tersebut, diketahui bahwa sampel penelitian adalah sebanyak 93 responden. Berdasarkan rumus, maka ukuran sampel yang digunakan adalah 93 orang, dan kepada 93 responden tersebut akan disebarkan kuesioner penelitian. Jenis data dalam penelitian ini meliputi data primer dan sekunder. Data primer didapat dari penelitian lapangan, yaitu dengan melakukan penelitian langsung di Unit Pelaksana Pelayanan Terpadu Satu Pintu Kota Administrasi Jakarta Barat yang menjadi obyek penelitian untuk mendapatkan data, informasi, dan keterangan lain yang diperlukan. Teknik yang digunakan berupa kuesioner.

Selanjutnya untuk mengetahui Koefisien Korelasi Pengaruh Kompetensi pegawai (X1) dan Iklim Organisasi (X2) secara bersamaan terhadap Kualitas Pelayanan (Y), penulis menggunakan teknik Regresi dan Korelasi Berganda. Dimana regresi linier berganda didasarkan pada hubungan fungsional atau kausal dua variabel independen atau lebih dengan satu variabel dependen.

\section{HASIL DAN PEMBAHASAN}

Berdasarkan 3 hipotesis yang ditetapkan sebelumnya, selanjutnya dilakukan pengujian hipotesis untuk menguji kebenaran apakah terdapat pengaruh Kompetensi Pegawai $\left(\mathrm{X}_{1}\right)$ dan Iklim Organisasi $\left(\mathrm{X}_{2}\right)$ terhadap terhadap Kualitas Pelayanan di Unit Pelaksana Pelayanan Terpadu Satu Pintu Kota Administrasi Jakarta Barat (Y) baik secara parsial maupun secara simultan.

Berdasarkan rancangan uji Hipotesis yang diajukan dalam penelitian ini adalah sebagai berikut :

Hipotesis $1\left(\mathbf{H}_{0}=\mathbf{b}_{1}=\mathbf{0} ; \mathbf{H}_{1}=\mathbf{b}_{1} \neq \mathbf{0}\right)$

$\mathrm{H}_{0}=$ Tidak terdapat pengaruh positif Kompetensi Pegawai Terhadap Kualitas Pelayanan di Unit Pelaksana Pelayanan Terpadu Satu Pintu Kota Administrasi Jakarta Barat.

$\mathrm{H}_{1}=$ Terdapat pengaruh positif Kompetensi Pegawai Terhadap Kualitas Pelayanan di Unit Pelaksana Pelayanan Terpadu Satu Pintu Kota Administrasi Jakarta Barat.

Hipotesis $2\left(\left(\mathbf{H}_{0}=\mathbf{b}_{2}=\mathbf{0} ; \mathbf{H}_{1}=\mathbf{b}_{2} \neq \mathbf{0}\right)\right.$

$\mathrm{H}_{0}=$ Tidak terdapat pengaruh positif Iklim Organisasi Terhadap Kualitas Pelayanan di Unit Pelaksana Pelayanan Terpadu Satu Pintu Kota Administrasi Jakarta Barat.

$\mathrm{H}_{1}=$ Terdapat pengaruh positif Iklim Organisasi Terhadap Kualitas Pelayanan di Unit Pelaksana Pelayanan Terpadu Satu Pintu Kota Administrasi Jakarta Barat. 
Pengujian terhadap hipotesis 1 dan 2 dilakukan dengan penetapan uji t tersebut di atas.

Hipotesis $3\left(\mathbf{H}_{0}=\mathbf{b}_{1}=\mathbf{b}_{2}=\mathbf{0} ; \mathbf{H}_{1}=\mathbf{b}_{1} \neq \mathbf{b}_{2} \neq \mathbf{0}\right)$

$\mathrm{H}_{0}=$ Tidak terdapat pengaruh positif Kompetensi Pegawai Dan Iklim Organisasi secara bersama-sama Terhadap Kualitas Pelayanan di Unit Pelaksana Pelayanan Terpadu Satu Pintu Kota Administrasi Jakarta Barat.

$\mathrm{H}_{1}=$ Terdapat pengaruh positif Kompetensi Pegawai Dan Iklim Organisasi secara bersamasama Terhadap Kualitas Pelayanan di Unit Pelaksana Pelayanan Terpadu Satu Pintu Kota Administrasi Jakarta Barat.

Dengan kriteria uji hipotesis sebagai berikut :

Jika $t$ penelitian $>\mathrm{t}$ table, maka Ho ditolak dan $\mathrm{H}_{1}$ diterima

Jika t penelitian $<\mathrm{t}$ table, maka Ho diterima dan Hi ditolak

Atau membandingkan besarnya angka signifikansi (sig) penelitian dengan taraf signifikansi sebesar 0,05 , dengan kriteria sebagai berikut :

Jika sig penelitian $<0,05$, maka Ho ditolak dan $\mathrm{H} 1$ diterima

Jika sig penelitian > 0,05, maka Ho diterima dan $\mathrm{H} 1$ ditolak

\section{Pengaruh Kompetensi Pegawai terhadap Kualitas Pelayanan di Unit Pelaksana Pelayanan Terpadu Satu Pintu Kota Administrasi Jakarta Barat.}

Berdasarkan hasil penelitian dengan perhitungan statistik menunjukkan bahwa koefisien jalur antara Kompetensi Pegawai dan Kualitas Pelayanan di Unit Pelaksana Pelayanan Terpadu Satu Pintu Kota Administrasi Jakarta Barat dijelaskan sebagai berikut :

Tabel 2. Tabel Uji t. Penelitian X1

\begin{tabular}{|c|c|c|c|c|c|c|c|c|c|c|}
\hline & \multicolumn{7}{|c|}{ Coefficients $^{\mathrm{a}}$} & & & \\
\hline \multirow[b]{2}{*}{ Model } & \multicolumn{2}{|c|}{$\begin{array}{c}\text { Unstandardized } \\
\text { Coefficients }\end{array}$} & \multirow{2}{*}{\begin{tabular}{|c|}
$\begin{array}{c}\text { Standardized } \\
\text { Coefficients }\end{array}$ \\
Beta
\end{tabular}} & \multirow[b]{2}{*}{$\mathrm{t}$} & \multirow[b]{2}{*}{ Sig. } & \multicolumn{2}{|c|}{$\begin{array}{c}95.0 \% \\
\text { Confidence } \\
\text { Interval for B } \\
\end{array}$} & \multicolumn{3}{|c|}{ Correlations } \\
\hline & $\mathrm{B}$ & $\begin{array}{l}\text { Std. } \\
\text { Error }\end{array}$ & & & & $\begin{array}{l}\text { Lower } \\
\text { Bound }\end{array}$ & $\begin{array}{l}\text { Upper } \\
\text { Bound } \\
\end{array}$ & $\begin{array}{l}\text { Zero- } \\
\text { order }\end{array}$ & $\begin{array}{c}\text { Partia } \\
1\end{array}$ & Part \\
\hline 1 (Constant) & .301 & 1.107 & & .272 & .786 & -1.898 & 2.500 & & & \\
\hline $\mathrm{x} 1$ & .763 & .148 & .446 & $\begin{array}{c}5.17 \\
1\end{array}$ & .000 & .470 & 1.056 & .978 & .479 & .094 \\
\hline
\end{tabular}

a. Dependent Variable: y

Besarnya angka t table di hitung dengan ketentuan sebagai berikut

Taraf signifikansi 0,05

Derajat Kebebasan (DK) : n -2, atau 93-2 =91

Dari ketentuan tersebut diperoleh t table sebesar 1.960

Berdasarkan hasil perhitungan, diperoleh angka $\mathrm{t}$ penelitian sebesar $5.171>\mathrm{t}$ table sebesar 1.960. Selain itu dengan membandingkan angka signifikansi penelitian $0,000<0,05$, maka dapat disimpulkan Ho ditolak dan Hi diterima. Artinya Ada hubungan linier antara Kompetensi Pegawai dengan Kualitas Pelayanan di Unit Pelaksana Pelayanan Terpadu Satu Pintu Kota Administrasi Jakarta Barat.

Selanjutnya nilai komponen regresi yang diperoleh adalah berdasarkan persamaan regresi tersebut di atas, diperoleh nilai koefisien regresi (b) yaitu sebesar 0,446. Nilai ini merupakan besarnya pengaruh Kompetensi Pegawai dengan Kualitas Pelayanan di Unit Pelaksana Pelayanan Terpadu Satu Pintu Kota Administrasi Jakarta Barat. Hal ini membawa arti bahwa setiap perubahan variabel $\mathrm{X}_{1}$ 
(Kompetensi Pegawai) akan diimbangi dengan perubahan variabel Y (Kualitas Pelayanan di Unit Pelaksana Pelayanan Terpadu Satu Pintu Kota Administrasi Jakarta Barat). Karena nilai b =0,446 ternyata positif, maka tiap pertambahan pada variabel Kompetensi Pegawai akan diimbangi dengan pertambahan Kualitas Pelayanan di Unit Pelaksana Pelayanan Terpadu Satu Pintu Kota Administrasi Jakarta Barat. Adapun besarnya pengaruh Kompetensi Pegawai terhadap Kualitas Pelayanan di Unit Pelaksana Pelayanan Terpadu Satu Pintu Kota Administrasi Jakarta Barat sebesar 0,446 atau 46.6 \%.

Hasil pengujian hipotesis menunjukkan bahwa t hitung 5.171 > t tabel 1.960 atau Ho ditolak H1 diterima, yaitu terdapat pengaruh positif Kompetensi Pegawai $\left(\mathrm{X}_{1}\right)$ terhadap Kualitas Pelayanan di Unit Pelaksana Pelayanan Terpadu Satu Pintu Kota Administrasi Jakarta Barat (Y). Hasil uji ini berarti $\mathrm{H}_{0}$ ditolak dan $\mathrm{H}_{1}$ diterima dan sekaligus membenarkan bahwa hipotesis pertama yang diajukan dapat diterima, yakni terdapat hubungan positif Kompetensi Pegawai terhadap Kualitas Pelayanan di Unit Pelaksana Pelayanan Terpadu Satu Pintu Kota Administrasi Jakarta Barat. Sedangkan dari hasil pengukuran dengan koefisien korelasi, pengaruh variabel Kompetensi Pegawai terhadap variabel terikat Kualitas Pelayanan di Unit Pelaksana Pelayanan Terpadu Satu Pintu Kota Administrasi Jakarta Barat menunjukkan nilai yang positif dan signifikan. Hal ini memberikan arti bahwa hubungan tersebut mempunyai keterkaitan hubungan yang erat dan searah.

Nilai regresi $\left(b_{1}\right)$ sebesar 0,446 . Penambahan dan atau pengurangan setiap 0,446 akan mempengaruhi penambahan atau pengurangan sebesar 0,446 terhadap variabel Y yaitu Kualitas Pelayanan di Unit Pelaksana Pelayanan Terpadu Satu Pintu Kota Administrasi Jakarta Barat. Artinya, apabila terjadi peningkatan dalam Kompetensi Pegawai kerja, akan mempengaruhi Kualitas Pelayanan di Unit Pelaksana Pelayanan Terpadu Satu Pintu Kota Administrasi Jakarta Barat. Demikian halnya apabila terjadi penurunan pada mutu Kompetensi Pegawai akan mempengaruhi hasil Kualitas Pelayanan di Unit Pelaksana Pelayanan Terpadu Satu Pintu Kota Administrasi Jakarta Barat.

\section{Pengaruh Iklim Organisasi terhadap Kualitas Pelayanan di Unit Pelaksana Pelayanan Terpadu Satu Pintu Kota Administrasi Jakarta Barat.}

Berdasarkan hasil penelitian dengan perhitungan statistik menunjukkan bahwa koefisien jalur antara Iklim Organisasi dan Kualitas Pelayanan di Unit Pelaksana Pelayanan Terpadu Satu Pintu Kota Administrasi Jakarta Barat dijelaskan sebagai berikut :

Tabel 3. Tabel Uji t. Penelitian X2

Coefficients $^{\mathrm{a}}$

\begin{tabular}{|c|c|c|c|c|c|c|c|c|c|c|}
\hline \multirow[b]{2}{*}{ Model } & \multicolumn{2}{|c|}{$\begin{array}{l}\text { Unstandardized } \\
\text { Coefficients }\end{array}$} & \multirow{2}{*}{ 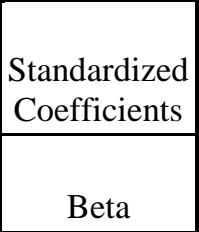 } & \multirow[b]{2}{*}{$\mathrm{t}$} & \multirow[b]{2}{*}{ Sig. } & \multicolumn{2}{|c|}{$\begin{array}{c}95.0 \% \\
\text { Confidence } \\
\text { Interval for B }\end{array}$} & \multicolumn{3}{|c|}{ Correlations } \\
\hline & B & Std. Error & & & & $\begin{array}{l}\text { Lower } \\
\text { Bound }\end{array}$ & $\begin{array}{l}\text { Upper } \\
\text { Bound }\end{array}$ & $\begin{array}{l}\text { Zero- } \\
\text { order }\end{array}$ & Partial & Part \\
\hline 1 (Constant) & .301 & 1.107 & & .272 & .786 & -1.898 & 2.500 & & & \\
\hline $\mathrm{x} 2$ & .950 & .150 & .545 & 6.315 & .000 & .651 & 1.249 & .981 & .554 & .115 \\
\hline
\end{tabular}

a. Dependent Variable: y

Besarnya angka $t$ table di hitung dengan ketentuan sebagai berikut

Taraf signifikansi 0,05

Derajat Kebebasan (DK) : n -2, atau 93-2 = 91

Dari ketentuan tersebut diperoleh $\mathrm{t}$ table sebesar 1.960

Berdasarkan hasil perhitungan, diperoleh angka t penelitian sebesar $6.315>\mathrm{t}$ table sebesar 1.960. Selain itu dengan membandingkan angka signifikansi penelitian $0,000<0,05$, maka dapat disimpulkan Ho ditolak dan Hi diterima. Artinya Ada hubungan linier antara Iklim Organisasi dengan Kualitas Pelayanan di Unit Pelaksana Pelayanan Terpadu Satu Pintu Kota Administrasi Jakarta Barat.

Selanjutnya nilai komponen regresi yang diperoleh adalah berdasarkan persamaan regresi tersebut di atas, diperoleh nilai koefisien regresi (b) yaitu sebesar 0, 545. Nilai ini merupakan besarnya pengaruh Iklim Organisasi dengan Kualitas Pelayanan di Unit Pelaksana Pelayanan Terpadu Satu Pintu Kota Administrasi Jakarta Barat. Hal ini membawa arti bahwa setiap perubahan variabel $\mathrm{X}_{2}$ (Iklim Organisasi) akan diimbangi dengan perubahan variabel Y (Kualitas Pelayanan di Unit 
Pelaksana Pelayanan Terpadu Satu Pintu Kota Administrasi Jakarta Barat). Karena nilai $b=0,545$ ternyata positif, maka tiap pertambahan pada variabel Iklim Organisasi akan diimbangi dengan pertambahan Kualitas Pelayanan di Unit Pelaksana Pelayanan Terpadu Satu Pintu Kota Administrasi Jakarta Barat. Adapun besarnya pengaruh Iklim Organisasi terhadap Kualitas Pelayanan di Unit Pelaksana Pelayanan Terpadu Satu Pintu Kota Administrasi Jakarta Barat sebesar 0, 545 atau 54,5 \%.

Hasil pengujian hipotesis menunjukkan bahwa t hitung 6.315 > t tabel 1.960 atau Ho ditolak H1 diterima, yaitu terdapat pengaruh positif Iklim Organisasi $\left(\mathrm{X}_{2}\right)$ terhadap Kualitas Pelayanan di Unit Pelaksana Pelayanan Terpadu Satu Pintu Kota Administrasi Jakarta Barat (Y). Hasil uji ini berarti $\mathrm{H}_{0}$ ditolak dan $\mathrm{H}_{1}$ diterima dan sekaligus membenarkan bahwa hipotesis pertama yang diajukan dapat diterima, yakni terdapat hubungan positif Iklim Organisasi terhadap Kualitas Pelayanan di Unit Pelaksana Pelayanan Terpadu Satu Pintu Kota Administrasi Jakarta Barat. Sedangkan dari hasil pengukuran dengan koefisien korelasi, pengaruh variabel Iklim Organisasi terhadap variabel terikat Kualitas Pelayanan di Unit Pelaksana Pelayanan Terpadu Satu Pintu Kota Administrasi Jakarta Barat menunjukkan nilai yang positif dan signifikan. Hal ini memberikan arti bahwa hubungan tersebut mempunyai keterkaitan hubungan yang erat dan searah.

Nilai regresi $\left(b_{2}\right)$ sebesar 0,545. Penambahan dan atau pengurangan setiap 0,545 akan mempengaruhi penambahan atau pengurangan sebesar 0,545 terhadap variabel Y yaitu Kualitas Pelayanan di Unit Pelaksana Pelayanan Terpadu Satu Pintu Kota Administrasi Jakarta Barat. Artinya, apabila terjadi peningkatan dalam Iklim Organisasi, akan mempengaruhi Kualitas Pelayanan Masyarakat Publik. Demikian halnya apabila terjadi penurunan pada mutu Iklim Organisasi akan mempengaruhi hasil Kualitas Pelayanan Masyarakat.

\section{Pengaruh Kompetensi Pegawai dan Iklim Organisasi secara bersama-sama terhadap Kualitas Pelayanan di Unit Pelaksana Pelayanan Terpadu Satu Pintu Kota Administrasi Jakarta Barat.}

Selanjutnya, hasil perhitungan untuk mengetahui seberapa besar pengaruh Kompetensi Pegawai $\left(\mathrm{X}_{1}\right)$ dan Iklim Organisasi $\left(\mathrm{X}_{2}\right)$ Terhadap Kualitas Pelayanan di Unit Pelaksana Pelayanan Terpadu Satu Pintu Kota Administrasi Jakarta Barat (Y) dilihat hasil penghitungan statistik dalam table model summary, khususnya angka R Square dibawah ini :

Tabel 4. Kompetensi Pegawai $\left(\mathrm{X}_{1}\right)$ dan Iklim Organisasi $\left(\mathrm{X}_{2}\right)$

Terhadap Kualitas Pelayanan di Unit Pelaksana Pelayanan Terpadu Satu Pintu Kota Administrasi Jakarta Barat (Y)

Model Summary ${ }^{b}$

\begin{tabular}{|l|r|r|r|r|}
\hline Model & \multicolumn{1}{|c|}{ R } & R Square & $\begin{array}{c}\text { Adjusted R } \\
\text { Square }\end{array}$ & $\begin{array}{c}\text { Std. Error of } \\
\text { the Estimate }\end{array}$ \\
\hline 1 & $.985^{\mathrm{a}}$ & .970 & .970 & 2.12116 \\
\hline
\end{tabular}

a. Predictors: (Constant), $\mathrm{x} 2, \mathrm{x} 1$

b. Dependent Variable: y

Besarnya angka $\mathrm{R}$ square $\left(\mathrm{r}^{2}\right)$ adalah 0.970. Angka tersebut merupakan angka besarnya pengaruh dengan cara menghitung Koefisien Determinasi (KD) dengan menggunakan rumus sebagai berikut :

$$
\begin{aligned}
& \mathrm{KD}=\mathrm{r}^{2} \times 100 \% \\
& \mathrm{KD}=0,970 \times 100 \% \\
& \mathrm{KD}=97 \%
\end{aligned}
$$

Angka tersebut mempunyai arti bahwa Kompetensi Pegawai $\left(\mathrm{X}_{1}\right)$ dan Iklim Organisasi $\left(\mathrm{X}_{2}\right)$ berpengaruh secara simultan terhadap Kualitas Pelayanan di Unit Pelaksana Pelayanan Terpadu Satu Pintu Kota Administrasi Jakarta Barat (Y) sebesar 97 \% Adapun sisanya sebesar 3 \% (100\% - 97 \%) dipengaruhi oleh faktor lain (epsilon).

Untuk mengetahui apakah model regresi tersebut sudah benar atau salah, diperlukan uji hipotesis. Uji hipotesis menggunakan angka F sebagaimana tertera dalam table di bawah ini.

Tabel 5. Hasil Uji Hipotesis Hubungan Linier Antar Variabel 
ANOVA ${ }^{b}$

\begin{tabular}{|ll|r|r|r|r|r|}
\hline Model & & Sum of Squares & df & Mean Square & F & Sig. \\
\hline 1 & Regression & 3264.473 & 2 & 632.237 & 474.049 & $.000^{\mathrm{a}}$ \\
& Residual & 404.940 & 90 & 4.499 & & \\
Total & 13669.413 & 92 & & & \\
\hline
\end{tabular}

a. Predictors: (Constant), $\mathrm{x} 2, \mathrm{x} 1$

b. Dependent Variable: $y$

Pengujian dilakukan dengan dua cara. Pertama, dengan membandingkan besarnya angka $\mathrm{F}$ penelitian dengan $\mathrm{F}$ table, dimana $\mathrm{F}$ penelitian dari SPSS sebesar $474.049>\mathrm{F}$ table sebesar 3.44 dan cara kedua ialah dengan membandingkan angka taraf signifikansi (sig) hasil penghitungan dengan taraf signifikansi 0,05 (5\%). Sehingga berdasarkan hasil yang diperoleh tersebut, maka Ho ditolak dan $\mathrm{H}_{1}$ diterima. Artinya ada hubungan linier antara Kompetensi Pegawai $\left(\mathrm{X}_{1}\right)$ dan Iklim Organisasi $\left(\mathrm{X}_{2}\right)$ secara simultan terhadap Kualitas Pelayanan di Unit Pelaksana Pelayanan Terpadu Satu Pintu Kota Administrasi Jakarta Barat (Y). Dengan demikian model regresi tersebut sudah layak dan benar.

Dengan diagram jalur sebagai berikut :

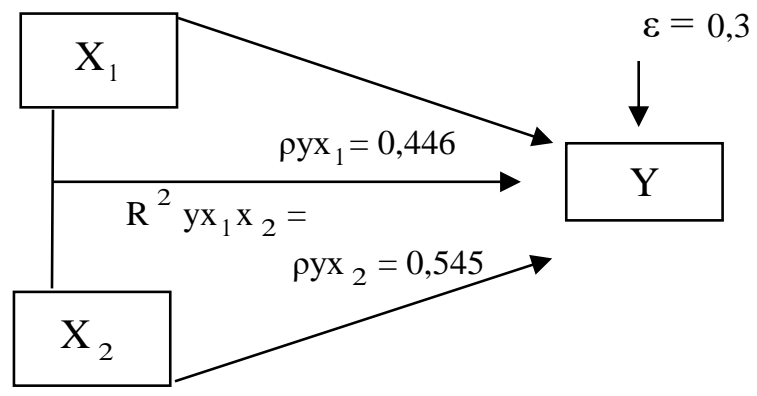

Dimana :

$\mathrm{X}_{1}=$ Kompetensi Pegawai

$\mathrm{X}_{2}=$ Iklim Organisasi

$\mathrm{Y}=$ Kualitas Pelayanan di Unit Pelaksana Pelayanan Terpadu Satu Pintu Kota Administrasi Jakarta Barat

Dengan demikian dapat menyatakan bahwa dengan kenaikan nilai dari variabel Kompetensi Pegawai $\left(\mathrm{X}_{1}\right)$ dan Iklim Organisasi $\left(\mathrm{X}_{2}\right)$ maka nilai Kualitas Pelayanan di Unit Pelaksana Pelayanan Terpadu Satu Pintu Kota Administrasi Jakarta Barat (Y).

Jika dilihat dari interpretasi Nilai $r$, maka pengaruh Kompetensi Pegawai $\left(\mathrm{X}_{1}\right)$ dan Iklim Organisasi $\left(\mathrm{X}_{2}\right)$ secara bersamana terhadap Kualitas Pelayanan di Unit Pelaksana Pelayanan Terpadu Satu Pintu Kota Administrasi Jakarta Barat (Y) sebesar 0,970 adalah tinggi (Antara 0,800 sampai dengan 1,00).

Hasil pengujian hipotesis menunjukkan bahwa angka $\mathrm{F}$ hitung $474.049>\mathrm{F}$ table sebesar 3.44 atau Ho ditolak H1 diterima, yaitu terdapat pengaruh positif Kompetensi Pegawai dan Iklim Organisasi $\left(\mathrm{X}_{2}\right)$ secara bersama-sama terhadap Kualitas Pelayanan di Unit Pelaksana Pelayanan Terpadu Satu Pintu Kota Administrasi Jakarta Barat (Y). Hasil uji ini berarti $\mathrm{H}_{0}$ ditolak dan $\mathrm{H}_{1}$ diterima dan sekaligus membenarkan bahwa hipotesis pertama yang diajukan dapat diterima, yakni terdapat hubungan positif Kompetensi Pegawai dan Iklim Organisasi terhadap Kualitas Pelayanan di Unit Pelaksana Pelayanan Terpadu Satu Pintu Kota Administrasi Jakarta Barat. Sedangkan dari hasil pengukuran dengan koefisien korelasi, pengaruh variabel Kompetensi Pegawai dan Iklim Organisasi terhadap variabel terikat Kualitas Pelayanan di Unit Pelaksana Pelayanan Terpadu Satu Pintu Kota Administrasi Jakarta Barat menunjukkan nilai yang positif dan signifikan. Hal ini memberikan arti bahwa hubungan tersebut mempunyai keterkaitan hubungan yang erat dan searah.

Nilai regresi $r$ squre sebesar 0,970. Penambahan dan atau pengurangan setiap 0,970 akan mempengaruhi penambahan atau pengurangan sebesar 0,970 terhadap variabel Y yaitu Kualitas 
Pelayanan di Unit Pelaksana Pelayanan Terpadu Satu Pintu Kota Administrasi Jakarta Barat. Artinya, apabila terjadi peningkatan dalam Kompetensi Pegawai dan Iklim Organisasi, akan mempengaruhi Kualitas Pelayanan di Unit Pelaksana Pelayanan Terpadu Satu Pintu Kota Administrasi Jakarta Barat. Demikian halnya apabila terjadi penurunan pada Kompetensi Pegawai dan Iklim Organisasi akan mempengaruhi hasil Kualitas Pelayanan di Unit Pelaksana Pelayanan Terpadu Satu Pintu Kota Administrasi Jakarta Barat.

\section{SIMPULAN DAN SARAN}

Dari hasil penelitian dapat ditarik kesimpulan sebagai berikut :

1. Hasil pengujian hipotesis menunjukkan bahwa t hitung 5.171 >t tabel 1.960 atau Ho ditolak H1 diterima, yaitu terdapat pengaruh positif Kompetensi pegawai (X1) terhadap Kualitas Pelayanan di Unit Pelaksana Pelayanan Terpadu Satu Pintu Kota Administrasi Jakarta Barat (Y). Sedangkan dari hasil pengukuran dengan koefisien korelasi, Nilai regresi (b1) sebesar 0,446. Penambahan dan atau pengurangan setiap 0,446 akan mempengaruhi penambahan atau pengurangan sebesar 0,446 terhadap variabel Y yaitu Kualitas Pelayanan di Unit Pelaksana Pelayanan Terpadu Satu Pintu Kota Administrasi Jakarta Barat.

2. Hasil pengujian hipotesis menunjukkan bahwa thitung $6.315>\mathrm{t}$ tabel 1.960 atau Ho ditolak H1 diterima, yaitu terdapat pengaruh positif Iklim Organisasi $\left(\mathrm{X}_{2}\right)$ terhadap Kualitas Pelayanan di Unit Pelaksana Pelayanan Terpadu Satu Pintu Kota Administrasi Jakarta Barat (Y). Sedangkan dari hasil pengukuran dengan koefisien korelasi, Nilai regresi $\left(b_{2}\right)$ sebesar 0,545 . Penambahan dan atau pengurangan setiap 0,545 akan mempengaruhi penambahan atau pengurangan sebesar 0,545 terhadap variabel Y yaitu Kualitas Pelayanan di Unit Pelaksana Pelayanan Terpadu Satu Pintu Kota Administrasi Jakarta Barat.

3. Hasil pengujian hipotesis menunjukkan bahwa angka $\mathrm{F}$ hitung $474.049>\mathrm{F}$ table sebesar 3.44 atau Ho ditolak H1 diterima, yaitu terdapat pengaruh positif Kompetensi pegawai dan Iklim Organisasi $\left(\mathrm{X}_{2}\right)$ secara bersama-sama terhadap Kualitas Pelayanan di Unit Pelaksana Pelayanan Terpadu Satu Pintu Kota Administrasi Jakarta Barat (Y). Sedangkan dari hasil pengukuran dengan koefisien korelasi, Nilai regresi $r$ squre sebesar 0,970. Penambahan dan atau pengurangan setiap 0,970 akan mempengaruhi penambahan atau pengurangan sebesar 0,970 terhadap variabel Y yaitu Kualitas Pelayanan di Unit Pelaksana Pelayanan Terpadu Satu Pintu Kota Administrasi Jakarta Barat.

Sehingga saran yang diajukan adalah :

1. Saran kepada Walikota Jakarta Barat : Perlu dikembangkan berbagai program pendidikan pelatihan dan pendekatan struktural yang terarah untuk meningkatkan kompetensi pegawai dalam rangka peningkatan Kualitas Pelayanan.

2. Saran kepada Kepala UPPTSP : perlunya untuk menjaga Iklim Organisasi di Unit Pelaksana Pelayanan Terpadu Satu Pintu Kota Administrasi Jakarta Barat seperti diantaranya semangat kerja tim dan hal-hal yang terkait dengan dukungan dan hubungan antar sesama rekan kerja yaitu perasaan saling menolong antara pimpinan dan staff, lebih ditekankan pada dukungan yang saling membutuhkan antara atasan dan bawahan, sehingga dapat mempercepat kinerja pelayanan di Unit Pelaksana Pelayanan Terpadu Satu Pintu Kota Administrasi Jakarta Barat.

3. Saran kepada pegawai : Agar dapat memenuhi standar kompetensi pegawai untuk menunjang tercapainya kualitas pelayanan yang optimal, diharapkan pegawai untuk terus meningkatkan kemampuan dan pengetahuan serta keterampilan tentang prinsip-prinsip dasar dan prosedur perizinan.

\section{DAFTAR PUSTAKA}

\section{Buku}

Davis K, Newstrom JW, 2001. Perilaku dalam Organisasi. Jilid 1, Terjemahan. Jakarta: Penerbit Erlangga.

Effendy, Onong. 2000. Ilmu Teori dan Filsafat Komunikasi. Bandung : PT.Rosdakarya. 
Hayes, J. 2000. Interpersonal Skills at Work. Retrived from: http://www.workpsychologyarena.com/books/book.asp?isbn=0415227755

Rahadian, AH. 2004, Mewujudkan Good Governance Melalui Pelayanan Publik, Jakarta: Jurnal Transparansi Vol.1 No.2; hal 57-70

Umar, Husein. 1999, Riset Sumber Daya Manusia Dalam Organisasi, Jakarta : P.T. Gramedia Pustaka Uatama.

\section{Dokumen}

Undang-Undang Nomor 25 tahun 2009 tentang Pelayanan Publik dijelaskan Pelayanan publik.

Peraturan Pemerintah Republik Indonesia Nomor 96 Tahun 2012 tentang Pelaksanaan UndangUndang Nomor 25 tahun 2009 tentang Pelayanan Publik.

Peraturan Presiden Nomor 97 Tahun 2014 tentang Penyelenggaraan Pelayanan Terpadu Satu Pintu.

Peraturan Daerah Nomor 12 Tahun 2013 tentang Penyelenggaraan Terpadu Satu Pintu.

Peraturan Gubernur Nomor 57 tahun 2014 tentang Pelaksanaan Peraturan Daerah Nomor 12 Tahun 2013 tentang Penyelenggaraan Pelayanan Terpadu Satu Pintu. 